\title{
Morphometric and flow cytometric analysis of small cell undifferentiated carcinoma of the bladder
}

\author{
C E M BLOMJOUS, W VOS, N W SCHIPPER, H J DE VOOGT,* J P A BAAK, \\ C J L M MEIJER \\ From the Departments of Pathology and *Urology, Free University Hospital, Amsterdam, The Netherlands
}

SUMMARY Eighteen cases of primary small cell carcinoma of the bladder were studied. Three patients survived for two years and one survived for five years, which was significantly worse when compared with poorly differentiated transitional cell carcinoma (WHO grade 3). Aggressive tumour î behaviour was independent of the presence of neuroendocrine characteristics. Morphometric analysis showed that the nuclear size, which was comparable with that reported in pulmonary small cell carcinoma, was significantly smaller than in poorly differentiated transitional cell carcinoma. Nuclear morphometry may therefore help identify small cell bladder carcinoma, especially in the absence of neuroendocrine differentiation characteristics. DNA flow cytometry of paraffin wax embedded specimens showed aneuploidy in 14 tumours - five were peritetraploid and two multiple aneuploid-and only three were diploid. Aggressiveness of small cell bladder carcinoma usually coincides with aneuploidy in most cases, but diploid tumours may also follow a rapid, lethal clinical course.

Primary small cell undifferentiated carcinoma rarely occurs outside the lung. ${ }^{2}$ In the bladder it accounts for less than $0.5 \%$ of all malignancies, ${ }^{3}$ but is characterised by an extremely aggressive course comparable with that of its pulmonary counterpart. ${ }^{34}$ Small cell bladder carcinoma may also show a favourable initial response to combination chemotherapy like pulmonary small cell undifferentiated carcinoma. ${ }^{3-6}$

Recognition of this type of bladder carcinoma is primarily based on histological appearance, which closely resembles that of pulmonary small cell carcinoma. Neuroendocrine differentiation characteristics identified by immunohistochemistry or electron microscopy may further elucidate diagnosis. ${ }^{3} \mathrm{~A}$ considerable number of cases may lack these features, however, even though they still follow a similarly fatal clinical course. ${ }^{348}$ Other additional diagnostic and prognostic techniques might therefore be useful.

Previous studies have shown that nuclear morphometry of transitional cell carcinoma is useful for discriminating among various histological grades and for predicting clinical outcome. ${ }^{69-11}$ The prevalence of large sized nuclei, for example, seems to be associated with high tumour grade and worse prognosis. ${ }^{910}$ Furthermore, flow cytometric studies have shown that DNA ploidy is of considerable prognostic importance

Accepted for publication 25 May 1989 in a variety of malignancies, ${ }^{12}$ including bladder ca cinoma. ${ }^{13-15}$ Like nuclear enlargement, DNA aneces ploidy has also been shown to be correlated with advanced tumour stage and unfavourable outcome. ${ }^{211}{ }^{16}$ So far, however, there are no data available which prove the value of these quantitative techniques in small cell bladder carcinoma.

\section{Material and methods}

The data of 18 patients ( 13 men, five women; mean age 68 years) with primary small cell undifferentiated carcinoma of the bladder were retrieved from the archives of the pathology laboratories of the Free University Hospital, Amsterdam, Antoni van Leeuwenhoek Hospital, Amsterdam, Reinier de Graaf 옥 Hospital (SSDZ) Delft, and the Regional Pathology $D$ Laboratory, Twente, in The Netherlands for the years 1975 to 1987. These 18 cases were taken from 3778 N consecutive patients with primary bladder malig- or nancy. Their clinicopathological features have been $\stackrel{N}{\circ}$ reported elsewhere. ${ }^{3}$ Histological and immuno- N histochemical preparations, electron microscopical 0 examination, and nuclear morphometric and DNA 6 flow cytometric analyses of the formalin fixed archival $\frac{D}{\Phi}$ material were performed at the department of patho- $\stackrel{\mathcal{D}}{+}$ logy of the Free University Hospital, Amsterdam.

Ten consecutive cases of primary and untreated 
poorly differentiated (WHO grade 3$)^{17}$ transitional cell carcinoma were taken from a previous morphometric study ${ }^{10}$ for comparison of morphometric characteristics and clinical follow up. Six of these patients had undergone transurethral resection (TURP) of their tumour, with subsequent radiation, and four had had cystectomy after having received radiotherapy first.

\section{HISTOLOGICAL AND IMMUNOHISTOCHEMICAL TECHNIQUES}

For conventional histological assessment $5 \mu \mathrm{m}$ sections were cut and stained with haematoxylin and eosin. Commercially available polyclonal and monoclonal antibodies were used for the immunohistochemical identification of epithelial and neuroendocrine differentiation characteristics (table 1). Various epithelial determinants were investigated, to take account of their variable expression in pulmonary small cell carcinomas. ${ }^{18}$ The antigens assessed included cytokeratin (directed to cytokeratins of various molecular heights from 40-65 kilodaltons), CAM $5 \cdot 2$ directed to cytokeratin components 8,18 , and 19), and epithelial membrane antigen (EMA). Furthermore, a panel of more or less specific neuroendocrine markers was used, including neuron specific enolase (NSE), chromogranin A, Leu-7, and synaptophysin. ${ }^{19-22}$ A positive reaction to NSE alone was regarded as insufficient immunohistochemical evidence for true neuroendocrine differentiation.
The staining procedures were performed exactly as described previously. ${ }^{23}{ }^{24}$ The techniques used were the indirect immunoperoxidase method, the unconjugated peroxidase-antiperoxidase method (PAP), and an avidine-biotin complex technique (table 1).

\section{ELECTRON MICROSCOPIC EXAMINATION}

Tissue for electron microscopical examination was obtained by dewaxing formalin fixed, paraffin wax embedded material. The recovered material was washed in $\mathbf{0 . 1} \mathrm{M}$ cacodylate buffer and post-fixed in $1 \%$ osmium tetraoxide in the same buffer. Semithin sections stained with toluidine blue were studied to ensure representative sampling. Ultrathin sections were stained with uranyl acetate and lead citrate and examined with a Zeiss 119 electron microscope.

\section{NUCLEAR MORPHOMETRY}

One representative haematoxylin and eosin stained slide of the primary tumour was selected for morphometric analysis from each specimen. Analysis was performed with a projection microscope, equipped with an oil immersion objective with a magnification of 100 times, projecting at a graphic tablet (MOPVideoplan, Kontron, Munich, West Germany) with an optical magnification of 2000 times.

Nuclear areas were measured according to a random as well as a selective morphometric method, as described previously. ${ }^{10}$ Briefly, the random method

Table 1 Immunohistochemical and electron microscopic findings in small cell bladder carcinoma

\begin{tabular}{|c|c|c|c|c|c|c|c|c|}
\hline \multicolumn{8}{|c|}{ Immunohistochemistry } & \multirow[b]{3}{*}{$\begin{array}{l}\text { Electron } \\
\text { microscopy } \\
\text { granules }\end{array}$} \\
\hline \multirow[b]{2}{*}{ Source } & \multirow{2}{*}{$\begin{array}{l}\text { EMA } \\
\begin{array}{l}\text { Dakopatts } \\
\text { monoclonal } \\
\text { IP }\end{array}\end{array}$} & \multirow{2}{*}{$\begin{array}{l}\text { CAM } 5 \cdot 2 \\
\text { Becton } \\
\text { Dickinson } \\
\text { monoclonal } \\
\text { ABC }\end{array}$} & \multirow{2}{*}{$\begin{array}{l}\begin{array}{l}\text { Cyto- } \\
\text { keratin }\end{array} \\
\text { Dakopatts } \\
\text { polyclonal } \\
\text { antibody } \\
\text { PAP }\end{array}$} & \multirow{2}{*}{$\begin{array}{l}\text { NSE } \\
\text { Dakopatts } \\
\text { polyclonal } \\
\text { antibody } \\
\text { PAP }\end{array}$} & \multirow{2}{*}{$\begin{array}{l}\begin{array}{l}\text { Chromo- } \\
\text { granin }\end{array} \\
\begin{array}{l}\text { Hybritech } \\
\text { monoclonal } \\
\text { IP }\end{array}\end{array}$} & \multirow{2}{*}{$\begin{array}{l}\text { Leu-7 } \\
\text { Becton } \\
\text { Dickinson } \\
\text { monoclona } \\
\text { IP }\end{array}$} & \multirow{2}{*}{$\begin{array}{l}\begin{array}{l}\text { Synapto- } \\
\text { physin }\end{array} \\
\text { Boehringer } \\
\text { Mannheim } \\
\text { monoclonal } \\
\text { IP }\end{array}$} & \\
\hline & & & & & & & & \\
\hline \multicolumn{9}{|c|}{ Case No } \\
\hline & ++ & - & + & ++ & - & - & + & - \\
\hline 2 & + & + & + & ++ & - & + & + & + \\
\hline 3 & ++ & - & + & ++ & - & - & + & - \\
\hline 4 & + & + & + & + & - & - & ++ & + \\
\hline 5 & ++ & ++ & $+t$ & ++ & ++ & - & ++ & + \\
\hline 6 & - & + & + & + & - & - & + & - \\
\hline 7 & ++ & + & - & ++ & + & ++ & ++ & + \\
\hline 8 & ++ & - & - & ++ & - & - & + & + \\
\hline 9 & ++ & - & - & ++ & - & - & ++ & - \\
\hline 10 & - & - & + & - & - & - & - & - \\
\hline 11 & + & - & + & - & - & - & - & - \\
\hline 12 & + & - & + & ++ & - & - & - & - \\
\hline 13 & + & ++ & ++ & + & - & - & - & + \\
\hline 14 & - & - & ++ & - & - & - & - & - \\
\hline 15 & ++ & - & + & $+t$ & + & + & ++ & + \\
\hline 16 & - & + & - & + & - & + & - & + \\
\hline 17 & ++ & ++ & ++ & ++ & + & - & + & - \\
\hline 18 & + & ++ & ++ & ++ & - & ++ & ++ & - \\
\hline
\end{tabular}

(-) negative, $(+)$ focally positive, $(++)$ positive.

ABC $=$ avidine-biotin complex technique, PAP $=$ unconjugated peroxidase antiperoxidase method, IP = indirect immunoperoxidase method. 
1034

comprises measurement of 100 arbitrary nuclei, sampled from randomly positioned fields throughout the whole slide, and selected by using an ocular square grid. ${ }^{10}$ The selective method essentially entails the measurement of 10 abnormal nuclei from each slide. ${ }^{10}$
Blomjous, Vos, Schipper, De Voogt, Baak, Meijer@ These nuclei were chosen because of their large size and were selected from the histologically most atypicalo area of the slide (size of the area about five low power fields at a magnification of 10 times). Distorted, poorly defined, and obviously tangentially sectioned
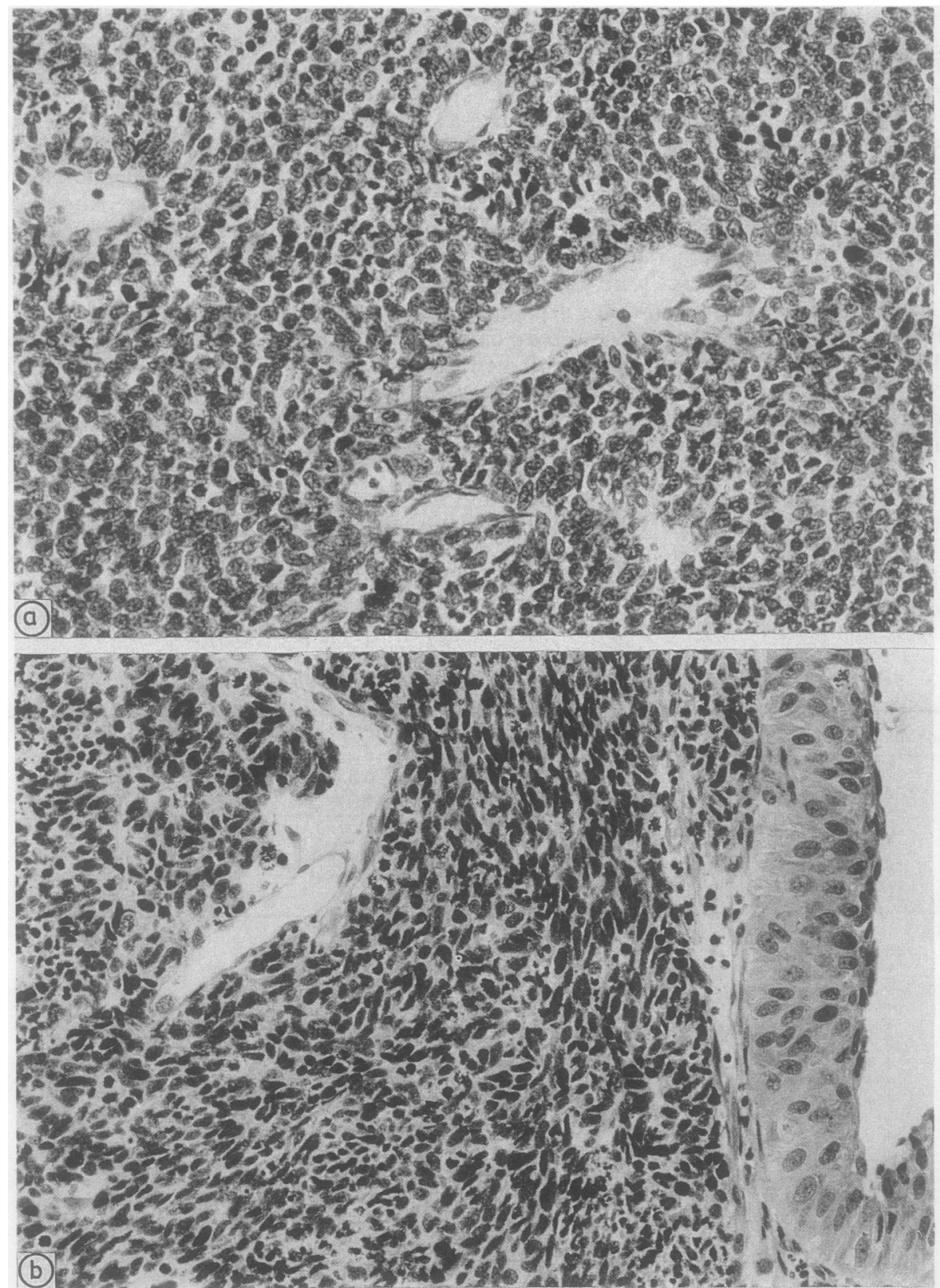

Figs $1 \mathrm{a}$ and $\mathrm{b}$ (a) Case 15: histological appearance of small cell undifferentiated bladder carcinoma. (b) Case 9: small cell carcinoma with slight atypia of the overlying urothelium. 
nuclei (nuclear caps) were not measured. As shown previously, both methods gave a satisfactory intraand interobserver reproducibility. ${ }^{10}$ Furthermore, they have been shown to discriminate effectively among various histological grades of transitional cell carcinoma, ${ }^{10}$ and the selective method, particularly, has shown that it is of considerable prognostic value. ${ }^{9}$

\section{DNA FLOW CYTOMETRY}

Nuclear DNA content in paraffin wax embedded specimens was analysed using the method described by Hedley et al, ${ }^{25}$ with slight modifications. Fifty $\mu \mathrm{m}$ thick sections were cut and dewaxed in xylol, rehydrated, and enzymatically dispersed by protease (Sigma $\mathrm{P} 5255,0.05 \%$ in $0.9 \%$ buffered saline, $\mathrm{pH} 7$ ). After filtration through a $50 \mu \mathrm{m}$ nylon gauze, centrifugation (for five minutes at $1000 \mathrm{rpm}$ ), resuspension in carbowax ( $2 \%$ polyethylene glycol in $50 \%$ ethanol), and mechanical detachment by repeated syringing (through 21 gauge needles) the cell suspension was centrifuged. The cells were stained with the DNA-fluorochrome 4',6'-diaminido-2-phenylindole dihydrochloride (final concentration $2 \mu \mathrm{g}$ DAPI/ $100 \mathrm{ml}$ Tris-hydrochloric acid buffer).

Nuclear DNA content was analysed with the PAS II flow cytometer (Partec Arlesheim, Switzerland), using excitation light at $350 \mathrm{~nm}$. Suspensions of mouse thymocytes were used for instrument setting. For each histogram 30000 to 80000 cells were scanned. The first modal cell peak was regarded as the diploid peak. Samples were considered to be aneuploid when in addition to the $\mathrm{G} 0 / \mathrm{Gl}$ and $\mathrm{G} 2 / \mathrm{M}$ peaks, one or more DNA peaks were detected. Tumours in which the proportion of peritetraploid cells (DNA indices between 1.9 and 2.1 ) exceeded $10 \%$ of the whole cell population were regarded as peritetraploid aneuploid.

Survival (Kaplan-Meier) curves were analysed, using the Mantel-Cox statistic. Wilcoxon's test was used to evaluate the differences of mean and standard deviation of the nuclear area among various tumour groups.

\section{Results}

The histological appearance of the 18 small cell bladder carcinomas conformed with the criteria developed by the World Health Organization for small cell undifferentiated carcinoma of the lung (fig 1$)^{26}$ Ten cases were of the oat cell type, and eight cases also showed an intermediate cell pattern. Furthermore, seven tumours were of the combined type as they showed additional foci of transitional cell carcinoma (cases 8, 9, 11, 14 and 17), adenocarcinoma (cases 1 and 4), or large cell undifferentiated carcinoma (case 4).

The immunohistochemical and ultrastructural features of the small cell components are summarised in table 1. Their epithelial nature was immunohistochemically affirmed by reactivity to at least one epithelial determinant (broad spectre cytokeratins, cytokeratin components 8,18 , and 19, and EMA). Immunoreactivity to two or more of the neuroendocrine markers was shown in $13(72 \%)$ cases. NSE and synaptophysin were the most sensitive markers. Reactivity to chromagranin A and Leu-7 was found only in a minority of cases. Two tumours showed a positive immunoreaction to only NSE, and another three cases were negative for all neuroendocrine markers.

Although ultrastructural investigation was impaired by suboptimal fixation of the formalin fixed paraffin wax embedded tissue, neurosecretory type granules (diameters of 150 to $250 \mathrm{~nm}$ ) were found in the cytoplasm of eight tumours (table 1). These dense, core membrane bound granules were commonly found only after prolonged examination.

Stage (TNM classification) of the initial tumour, treatment, development of metastases, and clinical outcome of the patients with small cell carcinoma are shown in table $2 .{ }^{27}$ Only one patient seemed to be cured by cystectomy, being free of disease after more than five years of follow up. Three patients were still alive, although with progressive recurrent and metastatic disease in spite of initial remission after combination chemotherapy. The remaining 14 patients all died of their tumour at one to 15 months of disease (median and mean: seven and 9.4 months).

The Kaplan-Meier survival curve of the patients with small cell undifferentiated carcinoma is shown in fig 2: two and five year survivals come to $28 \%$ and $19 \%$, respectively. Comparison with the patient group with grade 3 transitional cell carcinoma emphasises their extremely unfavourable clinical course (MantelCox: $4.563 ; p=0.03$ ).

\section{MORPHOMETRIC FINDINGS}

Nuclear morphometric analyses of the small cell carcinomas according to the random method of sampling showed mean and standard deviations of the nuclear area ranging from 33.60 to $54.55 \mu \mathrm{m}^{2}$, and from 4.69 to $10.66 \mu \mathrm{m}^{2}$. Mean and standard deviation of both were: $43 \cdot 21(6 \cdot 76) \mu \mathrm{m}^{2}$ and $7 \cdot 15(2 \cdot 10) \mu \mathrm{m}^{2}$. A significantly larger mean and standard deviation of the nuclear area were observed in grade 3 transitional cell carcinoma: $80.44(8.28) \mu \mathrm{m}^{2}$, and $21.34(5.85) \mu \mathrm{m}^{2}$ (Wilcoxon, 18.62 and 18.62; p < 0.0001).

Similar findings were obtained when using the selective morphometric method. The mean and standard deviation of the mean nuclear areas of the small cell carcinomas were $67.55(10 \cdot 19) \mu \mathrm{m}^{2}$ and 7.83 (1.9) $\mu \mathrm{m}^{2}$, and of the grade 3 transitional cell carcinomas were $194.70(42.08) \mu \mathrm{m}^{2}$ and $42.88(22.69) \mu \mathrm{m}^{2}$ 
Table 2 Clinical follow up and DNA flow cytometric findings in small cell bladder carcinoma

\begin{tabular}{|c|c|c|c|c|c|c|c|}
\hline Case & Age/Sex & Stage & Treatment & Metastases & Follow up & (months) & Ploidy state \\
\hline $\begin{array}{r}1 \\
2 \\
3 \\
4 \\
5 \\
6 \\
7 \\
8 \\
9 \\
10 \\
11 \\
12 \\
13 \\
14 \\
15 \\
16 \\
17 \\
18\end{array}$ & $\begin{array}{l}70 \mathrm{M} \\
55 \mathrm{M} \\
77 \mathrm{~F} \\
69 \mathrm{M} \\
68 \mathrm{M} \\
76 \mathrm{M} \\
70 \mathrm{~F} \\
71 \mathrm{~F} \\
59 \mathrm{M} \\
63 \mathrm{~F} \\
77 \mathrm{M} \\
81 \mathrm{M} \\
70 \mathrm{M} \\
65 \mathrm{M} \\
59 \mathrm{M} \\
50 \mathrm{M} \\
68 \mathrm{M} \\
73 \mathrm{~F}\end{array}$ & $\begin{array}{l}\text { T4 } \\
\text { T4 } \\
\text { T2 } \\
\text { T3 } \\
\text { T3 } \\
\text { T4 } \\
\text { T3 } \\
\text { T4 } \\
\text { T2 } \\
\text { T3 } \\
\text { T3 } \\
\text { T3 } \\
\text { T2 } \\
\text { T2 } \\
\text { T4 } \\
\text { T2 } \\
\text { T3 } \\
\text { T3 }\end{array}$ & $\begin{array}{l}\text { TUR, radiotherapy } \\
\text { TUR, radio-,"chemotherapy } \\
\text { TUR, radiotherapy } \\
\text { TUR, radiotherapy } \\
\text { *Chemotherapy, cystectomy } \\
\text { TUR, radiotherapy } \\
\text { TUR, radechotherapy } \\
\text { tTUR, chemothe } \\
\text { Cystectomy } \\
\text { Cystectomy } \\
\text { TUR, radiotherapy } \\
\text { Cystectomy } \\
\text { TUR, radiotherapy } \\
\text { TUR, radiotherapy } \\
\text { TUR, radiotherapy } \\
\text { TUR, radio-, fchemotherapy } \\
\text { Cystectomy, *chemotherapy } \\
\text { TUR, radiotherapy }\end{array}$ & $\begin{array}{l}\text { Yes } \\
\text { Yes } \\
\text { Yes } \\
\text { Yes } \\
\text { Yes } \\
\text { Yes } \\
\text { Yes } \\
\text { Yes } \\
\text { Yes } \\
\text { No } \\
\text { Yes } \\
\text { Yes } \\
\text { Yes } \\
\text { Yes } \\
\text { No } \\
\text { Yes } \\
\text { Yes } \\
\text { Yes }\end{array}$ & $\begin{array}{l}\text { Dead } \\
\text { Dead } \\
\text { Dead } \\
\text { Dead } \\
\text { Alive } \\
\text { Dead } \\
\text { Dead } \\
\text { Alive } \\
\text { Dead } \\
\text { Alive } \\
\text { Dead } \\
\text { Dead } \\
\text { Dead } \\
\text { Dead } \\
\text { Dead } \\
\text { Dead } \\
\text { Alive } \\
\text { Dead }\end{array}$ & $\begin{array}{l}(5) \\
(15) \\
(14) \\
(9) \\
(22) \\
(1) \\
(3) \\
(38) \\
(9) \\
(75) \\
(34) \\
(6) \\
(4) \\
(3) \\
(7) \\
(15) \\
(23) \\
(8)\end{array}$ & $\begin{array}{l}\text { Peritetraploid } \\
\text { Diploid } \\
\text { Peritetraploid } \\
\text { Multiple aneuploid } \\
\text { Multiple aneuploid } \\
\text { Diploid } \\
\text { Aneuploid } \\
\text { Peritetraploid } \\
\text { Peritetraploid } \\
\text { Peritetraploid } \\
\text { Diploid } \\
\text { Aneuploid } \\
\text { Aneuploid } \\
\text { Aneuploid } \\
\text { Aneuploid } \\
\text { Aneuploid } \\
\text { Aneuploid }\end{array}$ \\
\hline
\end{tabular}

* Methotrexate, cisplatin.

†Adriamycin, endoxan.

†Adriamycin, endoxan, vincristin; methotrexate, cisplatin.

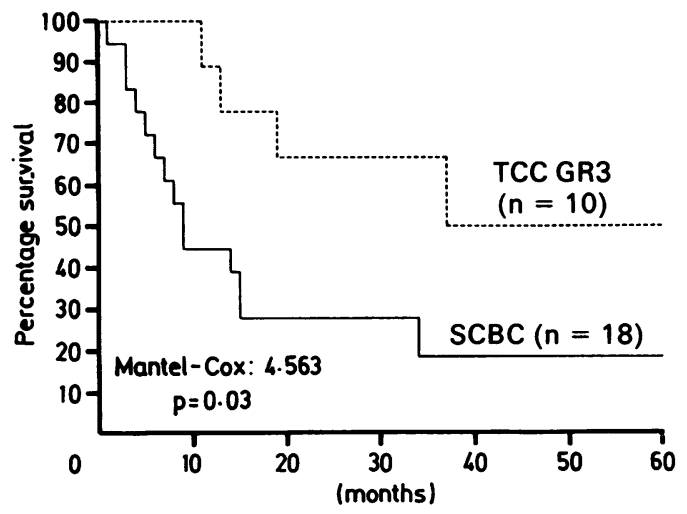

Fig 2 Kaplan-Meier survival curves of patients with small cell undifferentiated bladder carcinoma $(S C B C)$ and grade 3 transitional cell carcinoma (TCC GR 3).
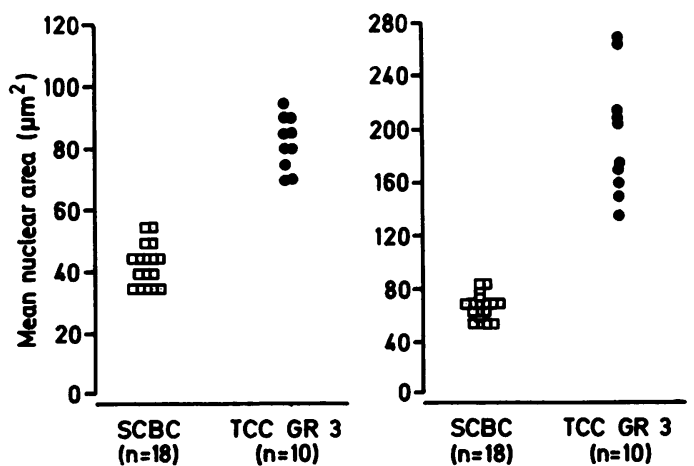

Fig 3 Distribution of the mean nuclear area $\left(\mu^{2}\right)$ of small cell bladder carcinoma (SCBC) and poorly differentiated transitional cell carcinoma (TCC GR 3), determined by two different morphometric methods. Left, random method; right, selective method.
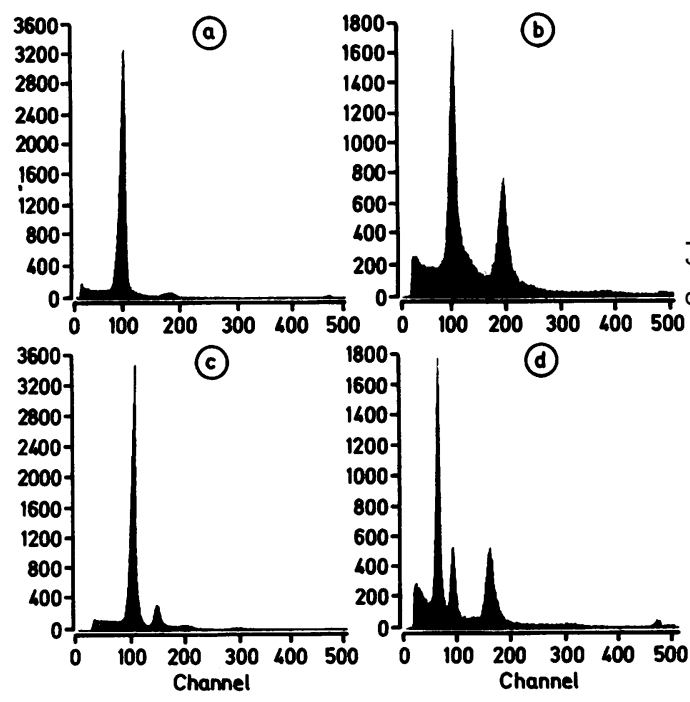

Fig 4 Flow cytometric DNA profiles of small cell bladder carcinoma. (a) Case 2, diploid; (b) case 8, peritetraploid; (c) case 14, aneuploid; (d) case 5, multiple aneuploid.

(Wilcoxon: 18.62 and 16.61; p $<0.0001$ ).

The values obtained by the selective method considerably exceeded those of the random method, or which was not surprising in view of the different methods of sampling.

Fig 3 illustrates the distribution of the mean nuclear areas determined by the random and selective method, showing the distinctly different nuclear size of both tumour types. No differences were observed between the mean and standard deviation of the nuclear area of the survivors and non-survivors among the patients with small cell undifferentiated carcinoma: random method, Wilcoxon 0.91 and $1.13, p=0.3$ and 
$\mathrm{p}=0.3$; selective method, Wilcoxon 0.41 and $0 \cdot 10$, $\mathrm{p}=0.5$ and $\mathrm{p}=0.8$.

There were also no differences between the mean and standard deviation of the nuclear area of the patients with and without neuroendocrine characteristics at immunohistochemical staining or at electron microscopic examination.

\section{DNA FLOW CYTOMETRY}

DNA histogram of the reprocessed paraffin wax embedded material generally showed relatively wide G0/G1 peaks with a coefficient of variation of $3 \cdot 1 \%$ to $10 \cdot 3 \%$ (mean $6 \cdot 8 \%$ ). Only one small cell carcinoma yielded an uninterpretable DNA histogram, consisting of a "noisy" baseline without recognisable peaks. The results are listed in table 2 and shown in fig 4. Three of the small cell tumours were diploid, and of the 14 aneuploid lesions, five had peritetraploid and two had multiple aneuploid tracings.

No correlation between the DNA pattern and the presence of neuroendocrine characteristics was found. Furthermore, none of the various DNA profiles (diploidy, aneuploidy, peritetraploidy or multiple aneuploidy) seemed to be significantly associated with distinct clinical outcome.

\section{Discussion}

This study shows that the prognosis of small cell bladder carcinoma is significantly more unfavourable than in poorly differentiated (WHO: grade 3 ) transitional cell carcinoma. The rapidly fatal outcome is comparable with that of small cell undifferentiated carcinoma of the lung. ${ }^{28}$ Clinical recognition of this rare type of bladder carcinoma is therefore important. This is corroborated by the fact that small cell bladder tumours may share a specific response to chemotherapy with pulmonary small cell carcinoma. ${ }^{36}$

Reported cases of small cell bladder carcinoma are sparse. ${ }^{147162329-31}$ Our studies indicate that the neoplasm, comprising about $0.5 \%$ of all primary bladder malignancies in the present series, is more common than is generally thought. This suggests that it is being underdiagnosed. As histological recognition, in general, does not seem to be too difficult, this may be partly due to unfamiliarity with this type of tumour in the urinary bladder.

Just as in the similar pulmonary neoplasm, the tumour should primarily be distinguished from other small cell neoplasms. in particular from malignant lymphomas. In case of doubt, the use of immunohistochemical markers (cytokeratins and EMA $v$ common leucocyte antigen) may be of help. ${ }^{3}$ Its differentiation from transitional cell carcinoma may be of more immediate concern. Although the nuclear size of small cell carcinoma lies within the same range as highly differentiated (WHO grade 1) transitional cell carcinoma ${ }^{10}$ histological discrimination is easy. In contrast to the latter, small cell carcinoma lacks the overt resemblance to urothelium and displays a diffuse and monotonous histological pattern, unlike the common papillary architecture of high grade transitional cell carcinoma.

Such differentiation characteristics are less common in poorly differentiated (grade 3 ) transitional cell carcinoma. This tumour is, however, characterised by a large and variable nuclear size, unlike small cell bladder carcinoma. ${ }^{32}$ This distinction is morphometrically reflected by the significantly lower values of the mean and standard deviation of the nuclear area in small cell carcinoma shown in this study. The values approach that of pulmonary small cell undifferentiated carcinomas which have been reported by others. ${ }^{33}$

Nuclear morphometry may thus help in doubtful cases to discriminate between poorly differentiated transitional cell carcinoma and small cell undifferentiated carcinoma. Its usefulness is especially apparent when immunohistochemistry and electron microscopy fail to disclose neuroendocrine differentiation characteristics, which occurred in a substantial number of our small cell carcinomas.

Within the group of small cell bladder carcinomas neither the use of the random nor the selective morphometric method permitted discrimination of any patient subgroup with distinct clinical outcome. This is at variance with previous morphometric observations in common transitional cell carcinoma that have shown a good correlation between nuclear size and prognosis. 910

DNA flow cytometry of paraffin wax embedded archival material enables the prognostic importance of nuclear DNA content to be evaluated retrospectively. It is, however, time consuming and not always accurate in the determination of near-diploid peaks, when compared with the processing of fresh tissue specimens..$^{25}$ The present analysis of archival material resulted in interpretable DNA histograms in 17 of the 18 tumours. Only one histogram was not evaluable, which might have been due to poor tissue fixation. Most of the remaining cases (14 of 17) had aneuploid cell populations; five of them were peritetraploid and two had multiple aneuploid peaks. Only three tumours were diploid, although we may have missed an additional near-diploid aneuploid peak in two of these cases because of their wide $\mathrm{G} 0 / \mathrm{G} 1$ peaks (coefficients of variation: $10 \cdot 3 \%$ and $7 \cdot 8 \%$ ).

No correlation was found between the various DNA patterns and clinical outcome. Irrespective of the ploidy state of the primary tumour, most patients developed early metastatic and fatal disease. In particular, the clinical course of the three diploid cases did 
not differ from the aneuploid cases. There is some difference in transitional cell carcinoma of the bladder, therefore, because DNA diploidy of this lesion is almost invariably associated with benign tumour behaviour. ${ }^{513}$

So far, there are no flow cytometric data available which permit comparison with our findings. Comparable data of small cell carcinoma of the lung are also scarce, although incidental reports indicate a similar predominance of aneuploid tumours. ${ }^{34} 35$ In this respect it is interesting that diploid pulmonary small cell carcinomas might show a better response to combination chemotherapy, as reported by some authors. ${ }^{36}$ Such a correlation was, however, not confirmed in our series. Only five of our patients received chemotherapy, resulting in temporary remission of the disease in all five patients and in prolonged survival in three, but all these cases had been shown to be aneuploid.

In conclusion, our study shows that small cell bladder carcinoma is a highly aggressive neoplasm that should be distinguished from other malignancies, including poorly differentiated transitional cell carcinoma. Identification should primarily be based on the light microscopical appearance, but nuclear morphometry may help to affirm the diagnosis, especially when immunohistochemistry and electron microscopy are inconclusive. Although flow cytometry shows an aneuploid nuclear DNA content in most of the cases with a fatal course, the absence of detectable DNA aneuploid cell populations does not indicate less aggressive tumour behaviour.

We are grateful to the following colleagues for the supply of their archival material: Dr J Delemarre of the Antoni van Leeuwenhoek Ziekenhuis, Amsterdam; Dr A A de la Fuente of the Pathologisch Streeklaboratorium Twente, Enschede; Dr J Lindeman of the Stichting Samenwerking Delftse Ziekenhuizen (SSDZ), Delft.

\section{References}

1 Ibrahim NBN, Briggs JC, Corbishley CM. Extrapulmonary oat cell carcinoma. Cancer 1984;54:1645-61.

2 Richardson RL, Weiland LH. Undifferentiated small cell carcinoma in extrapulmonary sites. Semin Oncol 1982;9:484-96.

3 Blomjous CEM, Vos W, De Voogt HJ, Van der Valk P, Meijer CJLM. Small cell undifferentiated carcinoma of the urinary bladder: a clinicopathological, immunohistochemical and ultrastructural study of 18 cases. Cancer 1989;(In press).

4 Mills SE, Wolfe JT, Weiss MA, et al. Small cell undifferentiated carcinoma of the urinary bladder. Am J Surg Pathol 1987; 11:606-17.

5 Davis BH, Ludwig ME, Cole SR, Pastuszak WT. Small cell neuroendocrine carcinoma of the urinary bladder: report of three cases with ultrastructural analysis. Ultrastruct Pathol 1983;4:197-204.

6 Ordonez NG, Khorsand J, Ayala AG, Sneige N. Oat cell
Blomjous, Vos, Schipper, De Voogt, Baak, Meijer

carcinoma of the urinary tract. Cancer 1986;58:2519-30.

$7 \mathrm{Kim}$ CK, Lin JI, Tseng CH. Small cell carcinoma of the urir $\mathrm{v}$. bladder. Urology 1984;24:384-6.

8 Lee JY, Tang C, Rodriguez F. Anaplastic carcinoma of the urinar, bladder with oat cell features. Urology 1986;27:474-6.

9 Blomjous CEM, Schipper NW, Baak JPA, Vos W, De Voogt HJ, Meijer CJLM. The value of morphometry and DNA flow cytometry in addition to classic prognosticators in superficial urinary bladder carcinoma. Am J Clin Pathol 1989;91:243-8.

10 Blomjous CEM, Smeulders AWM, Vos W, Baak JPA, Van Galen $\overline{\bar{S}}$ EM, Meijer CJLM. A comparative study in morphometric $\widetilde{\Phi}$ grading of transitional cell carcinoma of the urinary bladder. Anal Quant Cytol Histol 1989;(in press).

11 Helander K, Hofer PA, Holmberg G. Karyometric investigations on urinary bladder carcinoma, correlated to histopathological $\vec{O}$ grading. Virchows Arch (Pathol Anat) 1984;403:117-25.

12 Friedlander ML, Hedley DW, Taylor IW. Clinical and biological $\vec{\omega}$ significance of aneuploidy in human tumours. J Clin Pathol 1984;37:961-74.

13 Blomjous CEM, Schipper NW, Baak JPA, Van Galen EM, De Voogt HJ, Meijer CJLM. Retrospective study of the importance $\mathrm{N}$ of DNA flow cytometry of urinary bladder carcinoma. J Clin Pathol 1988;41:21-5.

14 Gustafson H, Tribukait B. Characterisation of bladder carcinoma by flow cytometric DNA analysis. Eur Urol 1985;11:410-17.

15 Tribukait B, Gustafson H, Esposti PL. The significance of ploidy and proliferation in the clinical and biological evaluation of $\mathrm{J}$ bladder tumours: a study of 100 untreated cases. Br J Urol $\rightarrow$ 1982;54:130-5.

16 Partanen S, Asikanen U. Oat cell carcinoma of the urinary bladder with ectopic adrenocorticotropic hormone production. Hum Pathol 1985;16:313-15.

17 Mostofi FK, Sobin LH, Torloni H. Histological typing of urinary bladder tumours. International histological classification of $\overrightarrow{0}$ tumours. No 10. Geneva: World Health Organization, 1973. 응

18 Moss F, Bobrow LG, Sheppard MN, et al. Expression of epithelia and neural antigens in small cell and non small cell lues? carcinoma. J Pathol 1986;149:103-11.

19 Gould VE, Lee I, Wiedenmann B, Moll R, Chejfac G, Franke WW. Synaptophysin: a novel marker for neurons, certain neuroendocrine cells, and their neoplasms. Hum Pathol 1986;17:979-83.

20 Said JW, Vimadalal S, Nash G, et al. Immunoreactive neuron- $\overrightarrow{\vec{A}}$ specific enolase, bombesin, and chromogranin as markers for 윽 neuroendocrine lung tumors. Hum Pathol 1985;16:236-40.

21 Wilson BS, Lloyd RV. Detection of chromogranin in neuroendocrine cells with a monoclonal antibody. Am J Pathol 1984;115:458-68.

22 Leader M, Collins M, Patel J, Henry K. Antineuron specific $\frac{\bar{O}}{0}$ enolase staining reactions in sarcomas and carcinomas: its lack $\overline{0}$ of neuroendocrine specificity. J Clin Pathol 1986;39:1186-92.

23 Blomjous CEM, Thunnissen FBTM, Vos W, De Voogt HJ, Meijer CJLM. Small cell neuroendocrine carcinoma of the urinary bladder: an immunohistochemical and ultrastructural evaluation of 3 cases with a review of the literature. Virchows Arch 0 (Pathol Anat) 1988;413:505-12.

24 Henzen-Logmans SC, Meijer CJLM, Ruiter DJ, Mullink H, Balm $D$ FJM, Snow GB. Diagnostic application of panels of antibodies in mucosal melanomas of the head and neck. Cancer 1988;61:702-11.

25 Hedley DW, Friedlander ML, Taylor IW, Rugg CA, Musgrove EA. Method for analysis of cellular DNA content of paraffin- O embedded pathological material using flow cytometry. J Histo- $\mathrm{W}$ chem Cytochem 1983;31:1333-5.

26 World Health Organization. Histological typing of lung tumours. International histological classification of tumours, No $1.2 \mathrm{nd}$ 을 edition. Geneva: World Health Organization, 1981.

27 Harmer MH. TNM classification of malignant tumours. Third $\stackrel{\mathscr{S}}{+}$ edition. Geneva: International Union against Cancer, 1978.

28 Radice PA, Matthews MJ, Ihde DC, et al. The clinical behavior of

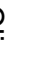


mixed small/large cell bronchogenic carcinoma compared to pure small cell subtypes. Cancer 1982;50:2894-902.

29 Cramer SF, Aikawa M, Cebelin M. Neurosecretory granules in small cell invasive carcinoma of the urinary bladder. Cancer 1981;47:724-30.

30 Reyes CV, Soneru I. Small cell carcinoma of the urinary bladder with hypercalcemia. Cancer 1985;56:2530-3.

31 Williams MR, Dunn M, Ansell ID. Primary oat cell carcinoma of the urinary bladder. Br J Urol 1986;58:225.

32 Koss LG. Tumors of the urinary bladder. Atlas of tumor pathology, Fascicle II. Washington, DC: Armed Forces Institute of Pathology, 1975.

33 Nomori H, Shimosato Y, Kodama T, Morinaga S, Nakajima T, Watanabe S. Subtypes of small cell carcinoma of the lung: morphometric, ultrastructural, and immunohistochemical analyses. Hum Pathol 1986;17:604-13.

34 Boehm N, Sandritter W. DNA in human tumors: a cytophotometric study. Curr Top Pathol 1975;60:152-219.

35 Vindelov LL, Hansen HH, Christensen IJ, et al. Clonal heterogeneity of small-cell carcinoma of the lung demonstrated by flowcytometric DNA analysis. Cancer Res 1980;40:4295-300.

36 Abe S, Tsuneta Y, Makimura S, Itabashi K, Nagai T, Kawakami $Y$. Nuclear DNA content as an indicator of chemosensitivity in small-cell carcinoma of the lung. Anal Quant Cytol Histol 1987;9:425-8.

Requests for reprints to: Dr C E M Blomjous. Department of Pathology, Free University Hospital, De Boelelaan 1117, 1007 MB Amsterdam, The Netherlands. 